\title{
Ebola: An International Public Health Emergency
}

Matheus Felipe Aguiar Santos ${ }^{1}$, Antonio Gilvan Teixeira Júnior ${ }^{1}$, Jucier Gonçalves Júnior ${ }^{1}$, Marcus Rafael Lobo Bezerra², Marcial Moreno Moreira ${ }^{3}$, Regiane Teixeira Silveira ${ }^{3}$, Jesus de Sousa Cartaxo ${ }^{3}$, Jorge André Cartaxo Peixoto ${ }^{3}$, João Marcos Ferreira de Lima Silva ${ }^{4}$, Francisco Antônio Vieira dos Santos ${ }^{4}$, Cicera Janielly de Matos Cassiano ${ }^{4}$, Patricia Gonçalves Pinheiro ${ }^{4}$, Carlos Augusto Carvalho de Vasconcelos ${ }^{5}$, Modesto Leite Rolim-Neto1,3,4

\section{Abstract}

The outbreak of Ebola in West Africa could become one of the worst infectious-disease-driven humanitarian crises of recent times. With more than 3000 deaths since the first case was confirmed in March 2014, the international community has recognized Ebola as a public health emergency of international concern and a clear threat to global health security. The complexity of dealing with this Ebola outbreak has highlighted the need for traditional actors, such as WHO and the CDC, to embrace the wider health and humanitarian community. The epidemic reinforces the need for nations to investment in health infrastructure and disease surveillance to keep pace with other developments in Africa. If Ebola arrives in high-income and middleincome nations, it should be contained quickly. The crisis shows the importance of sufficient levels of multilateral funding for WHO. The world needs a strong $\mathrm{WHO}$, with the financing and political influence to fulfil its historic mission.

\section{Keywords}

Ebola; Infectious disease; WHO
1 Faculty of Medicine, Federal University of Cariri, UFCA, Barbalha, Ceará, Brazil.

2 Department of Biochemistry and Molecular Biology. Federal University of Ceara, UFC, Fortaleza, Ceara, Brazil.

3 Postgraduate Program in Health Science. Faculty of Medicine of $A B C$, Santo André, São Paulo, Brazil.

4 Faculty of Medicine, Estacio - FMJ, Juazeiro do Norte, Ceara, Brazil.

5 Department of Neuropsychiatry, Federal University of Pernambuco, UFPE, Recife, Brazil.

\section{Comment}

The outbreak of Ebola in West Africa in March 2014 had the potential to become one of the worst infectious-disease-driven humanitarian crises of recent times. With five countries affected (Guinea, Sierra Leone, Liberia, Nigeria, and Senegal), more than 6500 cases of probable, confirmed, and suspected Ebola reported, and over 3000 deaths, this Ebola outbreak was the largest ever seen. Latest 
projections are concerning - the US Centers for Disease Control and Prevention (CDC) has estimated that Liberia and Sierra Leone could have up to 1.4 million cases of Ebola infection by January, 2015. [1, 2] With more than 3000 deaths since the first case was confirmed in March, 2014, and after months of slow and fragmented responses, the international community has recognized Ebola as a public health emergency of international concern and a clear threat to global health security. [3]

A filovirus infection hallmark (Ebola virus [EBOV] and Marburg virus [MARV]) is the rapid and potent suppression of innate antiviral immune responses, which facilitate uncontrolled viral replication and cytokine storm. $[4,5,6]$ As a result, high death rates of up to $90 \%$ are observed during outbreaks. $[6,7]$ Although this is the 25th outbreak since the disease was discovered in 1976, its unprecedented size brings into focus several issues around how the scientific community, governments, and the media should handle such events. [8]

The complexity of dealing with this Ebola outbreak has highlighted the need for traditional organizations, such as WHO and the CDC, to embrace the wider health and humanitarian community. The unfolding Ebola outbreak gave the event an additional dimension by highlighting the importance and potential of such network of institutes through in-house expertise and on-theground knowledge and presence. [9] It is worth noticing that human Ebola transmission has never occurred outside Africa. Sadly, the fragility of health systems is one of the reasons of why Ebola has been proved to be hard to stop in west Africa. [8]

Fragile health systems are unable to respond when a sudden, rapidly evolving emergency arises. Health workers are dealing with numerous issues they have not had to deal with to this extent when fighting Ebola in the past in central and east Africa. These include incredibly weak health systems, with few staff, little equipment, and poor facilities, making disease surveillance, isolation, and supportive care virtually impossible without external assistance. [10]

The major challenge of Ebola is containmentimplementation of isolation of suspected Ebola cases, infection control and universal precautions, contact tracing and monitoring, surveillance, and raised awareness in local communities and internationally. [2, 11, 12] Improved health system and infrastructure also have important collateral health benefits. [2, 13, 14] They do not only help prevent future outbreaks of Ebola and other diseases, but also improve the care for many other diseases. Thus, strengthening of health systems and infrastructure will have positive externalities for health promotion after this epidemic subsides. [2]

The epidemic reinforces the need for nations to investment in health infrastructure and disease surveillance to keep pace with other improvements in Africa. [8] Contribution to strengthening of local health systems and infrastructure is a benefit that funders should consider first, because it reinforces the general response to the epidemic and its causes. [2] Adoption of containment measures with a view to strengthen health systems and infrastructure is the most effective way to curb this epidemic and prevent future ones. [2]

A surge in cases since June, the first case in $\mathrm{Ni}$ geria in July, and the illness of the two Americans have now triggered a more proactive response from the international community. WHO sent a team of experts in late June and has issued a call for infection control professionals to work in affected countries. [8] The crisis shows the importance of sufficient levels of multilateral funding for WHO-the only international agency capable of coordinating the response to a health crisis with global dimensions. [10]

From our point of view, if Ebola arrives in highincome and middle-income nations, it should be 
contained quickly. A vaccine would probably exist today if Ebola affected a large number of people in high-income countries, making research and development financially attractive to drug companies-a situation that John Ashton, president of the UK Faculty of Public Health, has described as "the moral bankruptcy of capitalism acting in the absence of an ethical and social framework". [10]

The affected states possess fragile health systems that have proven to be unable to prevent Ebola's domestic and transnational spread. WHO itself is constrained. Its budget is incommensurate with its responsibilities, with an operating budget of a third of the US Centers for Disease Control and Prevention's budget. [15, 16, 17] After a 2011 funding shortfall, WHO cut its already insufficient budget by nearly US $\$ 600 \mathrm{mi}-$ llion. [16] The organization's emergency response units were reduced, with some epidemic control experts leaving the agency. $[17,18]$ The delayed and fragmented response to Ebola left a vacuum, which led to an unlikely plea from Médecins Sans Frontières for military deployment-logistics, engineering, and supply-chain management. [17,19] On September 16th, US President Barack Obama announced a military-led response in Liberia $[17,20]$ which could shore-up capacity but will not fill major governance deficits, which require UN action. [17]

The UN Secretary-General must act decisively to specify state responsibilities, set priorities, and coordinate activities. Resources need to be mobilized swiftly to build treatment facilities, train health workers, secure supply chains, and educate the public about Ebola. In our opinion, the Ebola crisis should become a turning point for WHO reform, and for its member states being willing to fully resource it. No agency can exert leadership when it controls only a small portion of a depleted budget. The World Health Assembly should substantially increase members' assessed contributions, create an emergency contingency fund, reform its regional organization, and engage non-state actors. [17, 21]

The world needs a stronger WHO, with the financing and political influence to fulfill its historic mission. The Ebola outbreak should push political actors to enact the far-reaching reforms needed. Global health leadership can be built, but only if genuine leaders choose to build it. [17]

\section{References}

1. WHO - Regional officer for Africa. Ebola virus disease, West Africa. [accessed Dec 5, 2014]. http://www.afro.who.int/en/ clusters-a-programmes/dpc/epidemica-pandemic-alert-andresponse/outbreak-news/4256-ebola-virusdisease-west-africa15-august-2014.html

2. Rid A, Emanuel EJ. Ethical considerations of experimental interventions in the Ebola outbreak. Lancet. 2014; 6736(14): 61315-5.

3. Gostin, L.O., Friedman, E.A. Ebola: what lessons for the International Health Regulations? Lancet, 2014; S01406736(14): 61697-4

4. Bray, M., and Murphy, F.A. Filovirus research: knowledge expands to meet a growing threat. J. Infect. Dis. 2007; 196 (Suppl 2): S438-S443

5. Geisbert, T.W., Young, H.A., Jahrling, P.B., Davis, K.J., Larsen, T., Kagan, E., Hensley, L.E. Pathogenesis of Ebola hemorrhagic fever in primatemodels: evidence that hemorrhage is not a direct effect of virus-induced cytolysisof endothelial cells. Am. J. Pathol. 2003; 163(6): 2371-2382.

7. Feldmann, H., and Geisbert, T.W. Ebola haemorrhagic fever. Lancet.2011; 377: 849-862.

6. Xu, W., Edwards, M.R., Dominika, M. Borek., Feagins, A.R. et al. Ebola Virus VP24 Targets a Unique NLS Binding Site on Karyopherin Alpha 5 to Selectively Compete with Nuclear Import of Phosphorylated STAT1. Cell Host Microbe.2014; 16(2): 187-200.

8. Trad, M., Fisher, D.A., Tambyah, P.A; Ebola in west Africa. The Lancet infectious diseases. 2014; S1473-3099(14): 70924-7

9. Ceschia, A. Institut Pasteur network: a crucial partner against Ebola. Lancet. 2014; 384(9950): 1239-1240.

10. Mullard, A. Ebola: a failure of international collective action. Lancet. 2014; 384(9944): 23-29

11. Fauci AS. Ebola-underscoring the global disparities in health care resources. N Engl J Med. 2014; 371: 1084-1086. 
12. WHO. WHO statement on the meeting of the international health regulations emergency committee regarding the 2014 Ebola outbreakin West Africa. [accessed Dec 5, 2014]. http://www. who.int/mediacentre/news/statements/2014/ebola-20140808/ en/

13. WHO. Everybody's business: strengthening health systems to improve health outcomes. WHO's framework for action. 2007. [accessed Dec 5, 2014].http://www.who.int/healthsystems/ strategy/everybodys_business.pdf

14. WHO. A conceptual framework for action on the social determinants of health. 2010. [accessed Dec 5, 2014]. http:// apps.who.int/iris/bitstream/10665/44489/1/9789241500852_ eng.pdf?ua=1\&ua=1

15. Department of the Health and Human Services -USA. Centers for Disease Control and Prevention. Budget Request SummaryFiscal Year 2015. 2014; 1-12. [accessed Dec 5, 2014]. http://www. cdc.gov/fmo/topic/Budget\%20Information/appropriations_ budget_form_pdf/FY2015_Budget_Request_Summary.pdf

16. WHO. Proposed programme budget 2014-2015. Geneva: World Health Organization, 2013. [accessed Sept 5, 2014]. http://apps. who.int/gb/ebwha/pdf_fi les/WHA66/A66_7-en.pdf .

17. Gostin, L.O., Friedman, E.A. Ebola: a crisis in global health leadership. Lancet. 2014; 384(9951): 1323-1325.

18. The New York Times. Cuts at W.H.O. Hurt Response to Ebola Crisis. Sept, 3, 2014. [accessed Sept 5, 2014]. http://www. nytimes.com/2014/09/04/world/africa/cuts-atwho-hurtresponse-to-ebola-crisis.html

19. Médecins Sans Frontières. Global bio-disaster response urgently needed in Ebola fight. Sept 2, 2014. [accessed Oct 2, 2014]. http://www.msf.org/article/global-bio-disasterresponseurgently-needed-ebola-fight

20. Cooper H, Fink S. Obama presses leaders to speed Ebola response. The New York Times. Sept 17, 2014. [accessed Oct 2, 2014]. http://www.nytimes.com/2014/09/17/world/africa/ obama-urges-world-powers-to-bolster-ebola-response.html.

21. Gostin LO. Global health law. Cambridge, MA: Harvard University Press, 2014.

\section{Comment on this article:}

\section{Qf $[$ in $8+\mathbf{S}$ P}

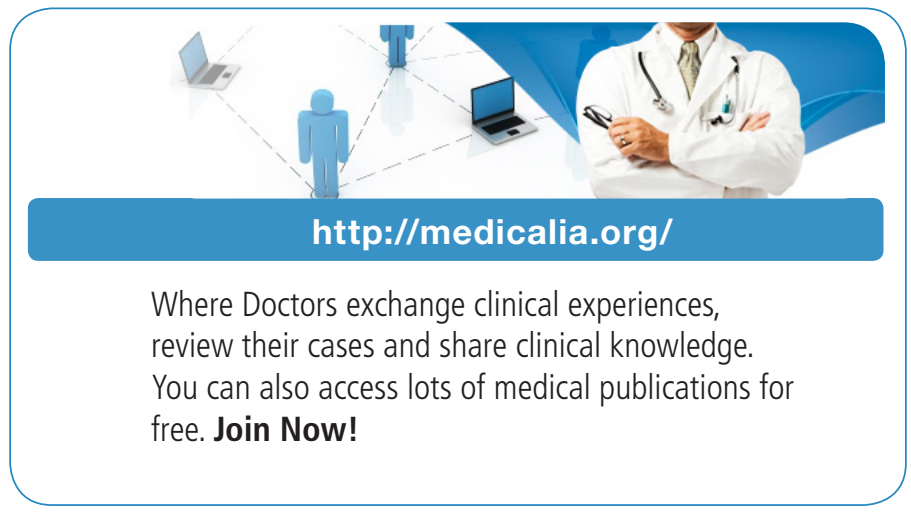

\section{Publish with iMedPub}

\section{http://www.imed.pub}

International Archives of Medicine is an open access journal publishing articles encompassing all aspects of medical science and clinical practice. IAM is considered a megajournal with independent sections on all areas of medicine. IAM is a really international journal with authors and board members from all around the world. The journal is widely indexed and classified Q1 in category Medicine. 